\title{
Pengembangan Usaha pada Kelompok Pengrajin Ukiran Batok Kelapa di Desa Tampaksiring Kabupaten Gianyar
}

\author{
Ida Ayu Dinda Priyanka Maharani ${ }^{1 *}$, Dewi Soraya², I Gst. B Ngr. P. Putra ${ }^{3}$, Putu Ary \\ Setiyawan ${ }^{4}$ (iD \\ 1,2,3 Universitas Warmadewa, Denpasar, Indonesia \\ *Corresponding author: priyanka88@gmail.com
}

\begin{abstract}
Abstrak
Batok kelapa merupakan salah satu bahan yang dapat digunakan sebagai produk kerajinan dan memiliki nilai jual yang cukup tinggi. Namun terdapat beberapa kendala yang dialami oleh pengrajin dalam proses produksi serta pemasaran produk kerajinan batok kelapa, seperti kurangnya pemahaman tentang strategi untuk meningkatkan usahanya, cara memasarkan produknya secara online dan tidak memiliki kemampuan dalam proses pencatatan transaksi keuangan yang baik. Untuk mengatasi permasalahan tersebut maka dilaksanan program kemitraan masyarakat dengan milbatkan 2 orang mitra yang merupakan pengrajin batok kelapa. Tujuan dari pelaksanaan program kemitraan ini adalah untuk meningkatkan hasil penjualan produk batok kelapa serta memperbaiki pola pencatatan keungan pengrajin. Terdapat 3 kegiatan yang dijalankan dalam program kemitraan masyrakat yakni sosialisasi strategi pemasaran, sosialisasi penggunaan website, dan sosialisasi proses pencatatan keuangan. Hasil pada pelaksanaan program menunjukkan bahwa setelah adanya kegiatan sosialisasi mitra mampu merancang strategi serta metode pemasaran yang lebih terstuktur, hasil lainnya menunjukkan bahwa mitra mampu menggunakan website untuk memasarkan produk yang dimilikinya, serta pencatatan keungan mitra menjadi lebih terstruktur, sehingga mengurangi kesalahan saat proses pencatatan keuangan.
\end{abstract}

Kata Kunci: Pengrajin Cangkang Kelapa, Sosialisasi Bauran Pemasaran, Bantuan Penggunaan Situs Web

\section{Abstract}

Coconut shell is one of the materials that can be used as a craft product and has a fairly high selling value. However, there are several obstacles experienced by craftsmen in the production process and marketing of coconut shell handicraft products, such as a lack of understanding of strategies to improve their business, how to market their products online and not having the ability to record good financial transactions. To overcome these problems, a community partnership program was carried out with the involvement of 2 partners who are coconut shell craftsmen. The purpose of implementing this partnership program is to increase the sales of coconut shell products and improve the pattern of financial recording of craftsmen. There are 3 activities carried out in the community partnership program, namely socialization of marketing strategies, socialization of the use of websites, and socialization of the financial recording process. The results of the program implementation show that after the socialization activities partners are able to design more structured marketing strategies and methods, other results show that partners are able to use websites to market their products, and partner financial records become more structured, thereby reducing errors during the financial recording process.

Keywords: Coconat Shell Croftsmen, Marketing Mix Socialization, Website Usage Assistance

\section{INTRODUCTION}

Kelapa merupakan salah satu tumbuhan yang sudah asing lagi di telingan masyarakat Indonesia, hal ini dikarenakan tumbuhan kelapa merupakan tumbuhan multi manfaat dan merupakan salah satu jenis tumbuhan dari suku aren-arenan atau Arecaceae (Ahmad et al., 2018; Kurniati \& Hariyanto, 2020). Hampir seluruh bagian dari pohon kelapa dapat dimanfaatkan oleh manusia, mulai dari akar,batang, bunga, buah sampai dengan daun dapat digunakan baik sebagai pengobatan tradisional ataupun untuk kehidupan sehari-hari seperti untuk bahan masakan dan kayu bakar, serta perabotan rumah tangga yang berbahan dasar

$\begin{array}{ll}\text { History: } & \\ \text { Received } & \text { : April 20, } 2021 \\ \text { Revised } & \text { : April 22, } 2021 \\ \text { Accepted } & \text { : May 16, } 2021 \\ \text { Published } & \text { : May 25, } 2021\end{array}$


pohon kelapa (Hermita, 2019). Pemanfaatan buah kelapa sebagai bahan baku makanan sehari-hari dan komoditas agro industru, menyisakan limbah berupa tempurung kelapa atau batok kelapa (Setyowati \& Puspa, 2019).

Tempurung kelapa adalah bagian terkeras yang dimiliki oleh buah kelapa, dimana tempurung kelapa ini memiliki ketebalan sekitar 3-5 mm (Eskak, 2016). Tempurung kelapa dapat dijadikan sebagai salah satu kerajinan yang memiliki nilai jual tinggi jika dapat diolah dan diproses dengan baik (Padnyawati et al., 2021). Salah satu daerah yang memanfaatkan tempurung kelapa sebagai bahan kerajinan adalah Desa Tampaksiring, Bali. Desa Tampksiring memiliki potensi sumber daya alam berupa pohon kelapa yang sangat meilimpah (Juniarta et al., 2013). Pada awalnya masyarakat Tampaksiring memanfaatkan pohon kelapa sebagai bahan pangan dan bangunan, mulai dari daun hingga akarnya bisa dimanfaatkan dengan baik oleh masyarakat setempat. Masyarakat di desa ini juga biasa mengolah buah kelapa sebagai minyak atau makanan yang berfariasi, sedangkan serabut dan batok kelapanya biasa dimanfaatkan sebagai arang atau bahan bakar pengganti kayu. Seiring dengan berjalannya waktu masyarakat desa Tampaksiring mulai memanfaatkan batok kelapa sebagai barang kerajinan yang bernilai ekonomis, dan diwariskan secara turun temurun.

Namun dengan adanya perkembangan arus globalisasi persaingan dunia usaha kerajinan semakin pesat. Para pengrajin harus mampu bersaing secara global dan memanfaatkan berbagai peluang yang ada untuk mempertahankan usaha yang dimilikinya (Sukmasetya et al., 2020). Di era serba teknologi seperti saat ini menuntut para pengusaha untuk bisa memanfaatkan peluang lewat media sosial baik berupa sosmed, jual beli online semua serba mudah dalam mempromosikan produk-produknya (Samsiana et al., 2020). Namun, para pemilik usaha kerajinan batok kelapa yang ada di Desa Tampaksiring memiliki hambatan dalam mengembangkan usahanya. Hal ini disampaikan oleh Bapak Sarjana dan Bapak Supurna selaku pengrajin batok kelapa. Beliau menyatakan bahwa para pengrajin batok kelapa di Desa Tampaksiring hanya memasarkan produknya melalui kios dan tidak memasarkannya secara online. Hal tersebut menjadi kendala tersendiri yang sangat serius, karena keberhasialan suatu usaha ditentukan oleh keberhasilan pemasaranya (Irfani et al., 2020). Sebab pemasaran memiliki peranan penting pada suatu bisnis, hal tersebut menjadi sebuah tolak ukur keberhasialan dalam menghadapi persaingan serta menjadi kunci keberhasilan suatu usaha maka pemasaran berperan besar dalam merealisasikan rencana usaha (Arifin \& Nurudin, 2020). Permasalahan lain yang dihadapi Bapak Sarjana dan Bapak Supurna yaitu belum memiliki kemampuan terkait proses pencatatan transaksi keuangan. Mitra sering mengalami kesulitan dalam menentukan aliran kas masuk dan keluar secara tepat. Proses pencatatan transaksi masih dilakukan secara manual. Permasalahan tersebut menjadi hal yang penting untuk diperhatikan karena berkaitan dengan aspek permodalan.

Berdasarkan hasil diskusi bersama Bapak Sarjana dan Bapak Supurna dapat diketahui bahwa terdapat 3 kendala utama yang dirasakan oleh para pengrajin di desa tampaksiring. Diantaranya adalah belum memiliki strategi pemasaran yang memumpuni sehingga mengakibatkan luas cakupan pangsa pasar produk masih sangat minim, mengalami permasalahan dalam proses pencatatan transaksi keuangan yang didasarkan atas kurangnya pengetahuan dan pemahaman terkait proses pencatatan keuangan sederhana, dan kurangnya kemampuan penggunaan teknolgi informasi sebagai media pemasaran. Upaya yang dapat dilakukan untuk mengatasi permasalahan tersebut yakni dengan memberikan sosialisasi strategi pemasaran, sosialisasi pembuatan website, dan sosialisasi proses pencatatan keuangan sederhana.

Strategi pemasaran merupakan rencana terpadu yang memberikan panduan mengenai kegiatan yang akan dijalankan guna tercapainya tujuan suatu usaha (Sahrupi \& Shofa, 2019). Sosialisasi strategi pemasaran membantu mitra untuk dapat memiliki gambaran yang jelas dan terarah mengenai apa yang akan dilakukan untuk menggunakan 
setiap kesempatan atau peluang yang ada dalam pemasaran, sehingga posisi mitra di pasar dapat dipertahankan sekaligus dapat ditingkatkan (Trianto \& ChoIvian, 2019). Strategi pemasaran yang akan ditawarkan dalam proses sosialisasi ini adalah strategi Bauran Pemasaran (marketing mix). Strategi tersebut menetapkan komposisi terbaik dari tujuh komponen pemasaran, untuk mencapai sasaran pasar yang dituju sekaligus mencapai tujuan usaha. Ketujuh komponen pemasaran tersebut terdiri dari product (produk), price (harga), promotion (promosi), place (tempat), partisipant (orang), process (proses), dan physical evidence (bukti atau fasilitas fisik) (Khoiriyah et al., 2017; Labatjo et al., 2018). Indikator capaian dari sosialisasi ini adalah mitra mampu menerapkan strategi pemasaran untuk meningkatkan posisi mitradi pasar.

Strategi pemecahan masalah selanjutnya yakni sosialisasi pembuatan website dengan tujuan untuk meningkatkan kemampuan penggunaan internet bagi pengrajin batok kelapa. Penerapan metode promosi online via Facebook apps dan Instagram apps. Melalui facebook apps penjual dapat melakukan optimalisasi kesadaran merk dengan membantu pengiklan untuk menemukan konsumen (Aprinta, 2016). Internet marketing memiliki lima keuntungan besar bagi perusahaan yang menggunakannya (Gumilang, 2019). Pertama, baik perusahaan kecil maupun perusahaan besar dapat melakukannya. Kedua, tidak terdapat batas nyata dalam ruang beriklan jika dibandingkan dengan media cetak dan media penyiaran. Ketiga, akses dan pencarian keterangan sangat cepat jika dibandingkan dengan surat kilat atau bahkan fax. Keempat, situsnya dapat dikunjungi oleh siapapun, dimanapun di dalam dunia ini, kapanpun. Kelima, belanja dapat dilakukan secara lebih cepat dan sendirian. Media internet ini bisa dijadikan sebagai sarana yang efektif untuk memperluas jaringan pemasaran produk keraj inan tempurung kelapa, sehingga calon konsumen bisa berhubungan langsung kepada pengrajin. Indikator capaian dari sosialisasi ini adalah mitra mampu membuat katalog berbasis online.

Adapun solusi pemecahan masalah yang ketiga yakni sosialisasi proses pencatatan keuangan sederhana. Laporan keuangan merupakan media bagi pengusaha untuk mengetahui pendapatan serta beban yang terjadi selama proses operasional dalam satu periode (Warsadi et al., 2017). Supaya mitra mengetahui kondisi keuangan usahanya, maka mitra perlu memahami cara untuk membuat laporan keuangan yang baik. Kami berencana melakukan sosialisasi pelatihan terkait proses pencatatan transaksi keuangan sederhana. Laporan yang dihasilkan mengandung informasi terkait aliran dana masuk dan keluar dalam aktivitas operasionalnya. Indikator capaian pada sosialisasi ini adalah mitra memperoleh kemampuan untuk menyusun laporan keuangan sederhana berupa laporan kas harian. Upaya pemecahan masalah ini dilaksanakan dalam Program Kemitraan Masyarakat dengan tujuan untuk meningkatkan keberlangsungan dari usaha kerajinan ukiran batok kelapa di Desa Tampaksiring tetap dilestarikan sebagai produk unggulan di Desa Tampaksiring dan tidak punah. Adapun bentuk pemberdayaan mitra yang akan dilaksanakan seperti program pendampingan mitra, pelatihan keahlian serta bantuan usaha dalam hal sarana dan prasarana.

\section{MATERIALS AND METHODS}

Program Kemitraan Masyarakat dilaksanakan di Desa Tampaksiring dengan mengajak 2 orang mitra yakni Bapak Sarjana dan Bapak Supurna selaku pengrajin batok kelapa. Program kemitraan masyrakat dilaksanakan selama 2 hari yakni pada tanggal 29 April dan 9 Mei 2021. Terdapat 3 program kerja yang dijalankan dalam kegiatan yakni sosialisasi strategi pemasaran, sosialisasi penggunaan website, dan sosialisasi proses pencatatan keuangan. Pada program pertama yakni, sosialisasi strategi pemasaran dilakukan oleh Ketua dibantu oleh anggota I. Proses sosialisasi terkait pentingnya strategi pemasaran dan strategi bauran pemasaran marketing mix). Materi yang disampaikan berkaikan dengan 
pentingnya proses pemasaran dan strategi promosi. Pada proses penyajian materi Mitra akan diberikan pemahaman bahwa strategi pemasaran mempunyai peranan penting untuk mencapai keberhasilan usaha dimana strategi pemasaran dapat memberi gambaran yang jelas dan terarah mengenai kegiatan yang akan dilakukan mitra dalam memaksimalkan setiap kesempatan atau peluang pada beberapa pasar sasaran.

Dan selanjutnya pada program kedua, yakni sosialisasi penggunaan website dilakukan oleh anggota III dengan dibantu oleh ketua pelaksana. Kegiatan sosialisasi dilakukan dengan metode penjelasan dan sharing. Pada metode penjelasan, anggota III dan ketua akan menyampaikan materi berupa power point kepada mitra terkait penggunaan website sebagai pemasaran digital. Di dalam menyampaikan penjelasannya anggota III dan ketua juga melakukan sharing atau berbagi pengalaman mengenai penggunaan digital marketing dalam promosi bisnis sehingga dapat memberikan gambaran lebih jelas kepada mitra. Melalui pemanfaatan teknologi informasi dan komunikasi tersebut diharapkan mitra dapat menghadapi persaingan usaha yang semakin ketat, selain itu mitra juga dapat meningkatkan pengetahuan mengenai sistem pemasaran digital atau sistem pemasaran online, sebab melalui sistem pemasaran digital atau sistem pemasaran online mitra akan lebih memahami tentang bagaimana cara memasarkan suatu produk sehingga jangkauan pasarnya semakin luas. Selanjutnya pada program ketiga yakni sosialisasi proses pencatatan keuangan, materi sosialisasi disajikan oleh anggota II dibantu oleh ketua. Materi yang akan diberikan pada sosialisasi ini terkait dengan pemahaman komponen laporan keuangan dan proses penyusunan laporan keuangan sederhana. Adapun laporan keuangan yang akan dipaparkan yaitu catatan kas harian.

\section{RESULTS AND DISCUSSION}

Pada tahap awal realisasi kegiatan pengabdian kepada masyarakat ini, kami berangkat dari perencanaan yang telah disusun sebelumnya. Pertama, dilakukan persiapan terkait materi yang akan disampaikan dan diberikan kepada mitra pengabdian. Ketua dan anggota I mempersiapkan materi tentang strategi pemasaran dengan marketing mix. Anggota II mempersiapkan materi terkait penyusunan laporan keuangan sederhana dan catatan kas harian Sementara anggota III mempersiapkan materi terkait sosialisasi penggunaan website. Selanjutnya, dilaksanakan kegiatan pengabdian ke lokasi mitra berpedoman pada jadwal pelaksanaan kegiatan yang telah disusun sebelumnya, tentunya dengan telah melakukan kesepakatan waktu pelaksanaan dengan mitra. Selain dilaksanakan proses persiapan segala sarana pendukung dilaksanakannya pengabdian ini seperti laptop, alat tulis, kamera serta buku peraga terkait materi yang akan disampaikan dan menerapkan protocol kesehatan.

Pelaksanaan kegiatan pengabdian kepada masyarakat dimulai dengan melakukan pertemuan dengan mitra pada tanggal 29 April 2021 terkait sosialisasi yang akan diberikan. Sosialisasi pertama yakni, penyampaian materi mengenai strategi pemasaran yang dilakukan oleh ketua tim pelaksana yang dibantu oleh anggota I. Sosialisasi strategi pemasaran dilakukan untuk memberikan pemahaman terkait manfaat dari strategi pemasaran yang dimana mempunyai peranan penting untuk mencapai keberhasilan usaha. Sosialisasi kedua, yakni penyampaian materi terkait terkait penyusunan laporan keuangan sederhana dan catatan kas harian. Media utama yang digunakan adalah laptop via aplikasi microsoft excel dan materi yang dipaparkan terkait saldo awal usaha, aliran kas masuk, aliran kas keluar, saldo akhir dan penyocokkan saldo akhir dengan saldo kas di tangan. Pada kunjungan sesi pertama ini, mitra nampak kurang paham terkait materi yang diberikan meskipun telah didukung dengan buku peraga catatan kas harian. Selain itu, penggunaan laptop dirasa kurang mobile bagi mitra. Pemaparan terkait materi laporan keuangan sederhana dan catatan kas kas harian kami akan lanjutkan pada sesi kunjungan kedua. 
Kunjungan kedua dilakukan tanggal 9 Mei 2021, dengan menggunakan media dan aplikasi yang lebih mudah dipahami oleh mitra terkait materi strategi pemasaran. Terdapat 3 kegiatan utama yang dilaksanakan pada kunjungan kedua, yakni: Kegiatan pertama, penyampaian materi terkait metode pemasaran berbasis marketing mix yang disampaikan oleh Ketua tim pelaksana PKM dan dibantu oleh anggota I. Strategi bauran pemasaran merupakan strategi yang dijalankan dimana kegiatannya berkaitan dengan penentuan bagaimana mitra dapat menawarkan produk pada segmen tertentu, yang menjadi sasaran pasarnya (Trianto \& ChoIvian, 2019). Marketing mix terdiri dari kombinasi variabel yang dapat mempengaruhi tanggapan para pembeli atau konsumen (Nurhadi, 2019). Ketujuh variabel tersebut adalah: Product, Price, Promotion, Place, Partisipant, Proses, dan Physical (Mohamad \& Rahim, 2021; Silaningsih \& Utami, 2018).

Pada aspek produk, dilakukan penekana kepada mitra agar memperhatikan desain produk untuk memenuhi kebutuhan pasar saat ini selain itu juga dilakukan pengembangan produk baru kepada mitra. Kemudian pada aspek price, dilakukan dengan memberikan discount pada reseller atau konsumen. Untuk aspek promotion, dilakukan dengan menyiapkan metode promosi secara online melalui media sosial disesuaikan dengan kebutuhan masyarakat saat ini. Selanjutnya untuk aspek place, dilakukan dengan menitipkan produk kerajinan ke beberapa artshop yang ada . Untuk aspek participant, mitra pengabdian telah mampu melibatkan masyarakat sekitar terkait produksi ataupun pemasaran serta mampu menciptakan lapangan pekerjaan dan meningkatkan perekonomian masyarakat Desa Tampaksiring. Aspek process, dilakukan dengan memperhatikan kualitas dari bahan baku kerajinan yaitu kelapa dengan menggunakan batok kelapa yang berwarna lebih putih. Dan yang terakhir yakni aspek physical evidence, mitra menginginkan dapat membuat berbagai maca, variasi ukiran pada batok kelapa. Oleh sebab itu, kami memberikan bantuan berupa alat bor khusus untuk pengrajin batok kelapa yaitu Bor gantung Foredom dan mata bor 2.5.

Hasil dari sosialisasi metode pemasaran berbasis marketing mix menunjukkan bahwa mitra telah mampu menyusun perencanaan dalam menunjang keberhasilan usahanya. Hal ini menunjukkan bahwa sosialisasi strategi serta metode pemasaran sangatlah dibutuhkan oleh mitra untuk penunjang peningkatan pejualan di era modern seperti saat ini. Strategi dan metode pemasaran dapat memberi gambaran yang jelas dan terarah mengenai kegiatan yang akan dilakukan mitra dalam memaksimalkan setiap kesempatan atau peluang pada beberapa pasar sasaran, sehingga posisi perusahaan di pasar dapat dipertahankan sekaligus dapat ditingkatkan (Arwani, 2019; Prasetyo \& Ruhandi, 2019; Zebua, 2018).

Kegiatan kedua yakni, sosialisasi penggunaan website yang dilakukan oleh anggota III dibantu oleh ketua. Proses sosialisasi terkait pemasaran digital (digital marketing) menggunakan media website dilakukan dalam beberapa tahap yakni, tahap pertama, sosialisasi dilakukan dengan metode penjelasan dan sharing. Pada metode penjelasan, anggota III dan ketua akan menyampaikan materi berupa power point kepada mitra terkait penggunaan website sebagai pemasaran digital.Dalam menyampaikan penjelasannya anggota III dan ketua juga melakukan sharing atau berbagi pengalaman mengenai penggunaan digital marketing dalam promosi bisnis sehingga dapat memberikan gambaran lebih jelas kepada mitra. Hasil dari kegiatan sosialisasi penggunaan website menunjukkan hasil bahwa mitra menjadi lebih siap dalam menghadapi persaingan usaha, serta cakupan jangkuan penjual yang lebih luas sehingga berdampak pada peningkatan jumlah penjualan.

Hasil pada tahap ini menunjukkan bahwa pemanfaatan teknologi informasi dan komunikasi sangatlah penting dalam menjalankan suatu usaha. Hal ini dikarenakan media internet merupakan salah satu sarana yang efektif untuk memperluas jaringan pemasaran produk kerajinan batok kelapa, sehingga calon konsumen bisa berhubungan langsung kepada pengrajin (Sholeh et al., 2020; Siagian et al., 2020). Sosial media menjadi salah satu unsur pendorong mitra untuk terus menggunakan dalam mengembangkan produk, melakukan 
komunikasi dengan konsumen dan pelanggan, penyalur, serta mengembangkan jaringan pasar yang lebih luas lagi, sehingga meningkatkan volume penjualan yang lebih besar (Harto et al., 2019).

Kegiatan ketiga, yakni sosialisasi mengenai tata cara pengoperasian aplikasi Buku Kas yang disampaikan oleh anggota II. Pada aplikasi Buku Kas telah tersedia secara lengkap menu yang berkaitan dengan pencatatan keuangan usaha (Putra, 2020). Pada sosialisasi mitra diperkenalkan dan diajrkan untuk input transaksi penjualan, harga pokok penjualan, input pengeluaran, pencatatan supplier ataupun pelanggan. Mitra juga dapat melakukan pencatatan terkait hutang dan piutang, serta mengatur pengingat tanggal jatuh temponya. Hasil pada sosialisasi mengenai tata cara pengoperasian aplikasi Buku Kas menunjukkan bahwa laporan yang dihasilkan menjadi alat kontrol untuk menyesuaikan saldo kas pada laporan dan saldo kas di tangan (cash on hand) serta Melalui sosialisasi ini mitra mampu meningkatkan kemampuan pembukuan meningkat, kesalahan pencatatan transaksi berkurang dan waktu penyusunan laporan keuangan lebih efisien. Hasil ini tidak terlepas dari sistem aplikasi yang mampu memberikan informasi pengingat bagi mitra terkait nama pelanggan ataupun supplier beserta nominal utang ataupun piutangnya (Ulfah \& Purfini, 2020). Aplikasi juga menyediakan menu terkait pembayaran hutang dan pelunasan piutang. Hal yang tak kalah pentingnya adalah mitra dapat mengunduh laporan hutang ataupun piutang serta laporan keuangan sederhana sesuai dengan jangka waktu yang diinginkan. Dengan segala kemudahan yang diberikan oleh aplikasi Buku Kas, sangat terlihat perbedaan antusiasme mitra dalam memperhatikan dan mempraktekkan aplikasi ini dibandingkan dengan pemaparan menggunakan media Microsoft excel pada kunjungan sebelumnya. Pencatatan transaksi keuangan dan penyediaan laporan keuangan sangat bermanfaat bagi mitra untuk mengetahui posisi keuangan serta hasil dari usaha yang dijalankan baik itu jangka waktu harian, mingguan atau bulanan. Output laporan yang dihasilkan juga mampu menjadi alat kontrol untuk menyesuaikan saldo kas pada laporan dan saldo kas di tangan (cash on hand). Selain pendampingan sosialisasi program kerja, pada kegiatan pengabdian ini kami tim pengabdi melakukan penyerahan bantuan berupa Bor Gantung boredom dan Mata Bor 2.5 kepada mitra sebagai bentuk dukungan terhadap program kerja yang ada pada strategi pemasaran (marketing mix) yaitu physical evidence.

\section{CONCLUSION}

Pelaksanaan Program Kemitraan Masyarakat pada usaha kerajinan batok kelapa dilaksanakan di desa Tampaksiring, Kabupaten Gianyar Bali, dengan melibatkan 2 orang mitra yakni Bapak Sarjana dan Bapak Supurna selaku pengrajin batok kelapa. Program kemitraan masyrakat dilaksanakan selama 2 hari yakni pada tanggal 29 April dan 9 Mei 2021. Terdapat 3 program kerja yang dijalankan dalam kegiatan yakni sosialisasi strategi pemasaran, sosialisasi penggunaan website, dan sosialisasi proses pencatatan keuangan. Hasil pada pelaksanaan program menunjukkan bahwa setelah adanya kegiatan sosialisasi mitra mampu merancang strategi serta metode pemasaran yang lebih terstuktur, hasil lainnya menunjukkan bahwa mitra mampu menggunakan website untuk memasarkan produk yang dimilikinya, serta pencatatan keungan mitra menjadi lebih terstruktur, sehingga mengurangi kesalahan saat proses pencatatan keuangan.

\section{REFERENCES}

Ahmad, A., Suyatman, M. A., Rahim, M. S., Majid, F., \& Hariance, R. (2018). Pengolahan batok (tampuruang) kelapa menjadi jam tangan botac (based on tampuruang andalas creation). Prosiding Seminar Nasional Aplikasi Sains \& Teknologi (SNAST), 329- 
335. https://journal.akprind. ac.id/index.php/prosidingsnast/article/view/1463/1162.

Aprinta, G. (2016). Pemanfaatan Facebook Ads Untuk meningkatkan Brand Awareness pada

Produk Lokal. Journal The Messenger, 8(1), 68-72. http://dx.doi.org/10.26623/themessenger.v8i1.310.

Arifin, J., \& Nurudin, N. (2020). Analisis pemasaran online kerajinan tempurung kelapa: studi kasus kerajinan tempurung kelapa “ONI MADE” Desa Ngemplak, Kecamatan Undaan, Kabupaten Kudus.

Arwani, A. (2019). Analisis Strategi Pemasaran Pengusaha Batik Kelurahan Banyurip Pekalongan Dengan Pendekatan Marketing Mix Berbasis Syariah. Li Falah: Jurnal Studi Ekonomi Dan Bisnis Islam, 4(1), 42. https://doi.org/10.31332/lifalah.v4i1.1345.

Eskak, E. (2016). Identifikasi Pola Laminasi Tempurung Kelapa. Dinamika Kerajinan Dan Batik: Majalah Ilmiah, 32(2), 107. https://doi.org/10.22322/dkb.v32i2.1366.

Gumilang, R. R. (2019). Implementasi Digital Marketing Terhadap Peningkatan Penjualan Hasil Home Industri. Jurnal Ilmiah Manajemen, 10(1), 9-14. https://journal.ikopin.ac.id/index.php/coopetition/article/view/25.

Harto, D., Pratiwi, S. R., Utomo, M. N., \& Rahmawati, M. (2019). Penerapan Internet Marketing Dalam Meningkatkan Pendapatan Pada UMKM. JPPM (Jurnal Pengabdian Dan Pemberdayaan Masyarakat), 3(1), 39. https://doi.org/10.30595/jppm.v3i1.3033.

Hermita, R. (2019). Memanfaatkan Limbah Batok Kelapa Menjadi Berbagai Macam Bentuk Kerajinan. Jurnal Proporsi, 4(2), 93-104. https://doi.org/http://dx.doi.org/10.22303/proporsi.4.2.2019.93-104.

Irfani, H., Yeni, F., \& Wahyuni, R. (2020). Pemanfaatan Digital Marketing Sebagai Strategi Pemasaran Pada Ukm Dalam Menghadapi Era Industri 4.0. JCES (Journal of Character Education Society), 3(3), 651-659. https://doi.org/https://doi.org/10.31764/jces.v3i3.2799.

Juniarta, P. E., Sudarmawan, A., \& Mursa. (2013). Seni Kerajinan Tempurung Kelapa Di Desa Tampaksiring, Kecamatan Tampaksiring, Kabupaten Gianyar. Jurusan Pendidikan Seni Rupa, https://doi.org/http://dx.doi.org/10.23887/jjpsp.v4i1.2136.

Khoiriyah, N., Widodo, J., \& Ani1, H. M. (2017). Strategi Bauran Pemasaran Kerajinan Tenun Ikat Pada CV. Silvi Mn Paradila Di Desa Parengan Kecamatan Maduran Kabupaten Lamongan. Jurnal Pendidikan Ekonomi, 1(1), 91-98. https://doi.org/https://doi.org/10.19184/jpe.v11i1.5007.

Kurniati, T., \& Hariyanto, D. (2020). Pelatihan Kerajinan Batok Kelapa di Desa Sungai Belidak. Buletin Al-Ribaath, 17(1), 17-20. https://doi.org/http://dx.doi.org/10.29406/br.v17i1.1874.

Labatjo, G. S., Loho, A. E., \& Pangemanan, L. R. J. (2018). Bauran Pemasaran Kerajinan Cenderamata Berbahan Baku Bambu Batik (Studi Kasus Pada UD. Betris di Kelurahan Meras Kecamatan Bunaken Kota Manado). Jurnal Agri-SosioEkonomi Unsrat, 14(1), 247-256. https://ejournal.unsrat.ac.id/index.php/jisep/article/view/19287/18841.

Mohamad, R., \& Rahim, E. (2021). Strategi Bauran Pemasaran (Marketing Mix) Dalam Perspektif Syariah. Jurnal Ekonomi Syariah IAIN Sultan Amai Gorontalo, 2(1), 1526. http://jurnal.uinsu.ac.id/index.php/humanfalah/article/view/4811/2863.

Nurhadi. (2019). Manajemen Strategi Pemasaran Bauran (Marketing Mix) Perspektif $\begin{array}{llll}\text { Ekonomi Syariah. } & \text { Human }\end{array}$ http://jurnal.uinsu.ac.id/index.php/humanfalah/article/view/4811/2863.

Padnyawati, K. D., Kusumawati, N. P. A., Trarintya, M. A. P., Pramuki, N. M. W. A., Erlinawati, N. W. A., \& Putra, C. G. B. (2021). Pendampingan Pemasaran Produk 
Dan Pelatihan Penyusunan Pembukuan Pada Umkm Kerajinan Batok Kepala Di Desa Timpag Kerambitan Tabanan. Jurnal Sewaka Bhakti, 6(1), 1-11. https://ejournal.unhi.ac.id/index.php/sewakabhakti pp. 1-11.

Prasetyo, E. Y., \& Ruhandi. (2019). Strategi Pemasaran Pengembangan Investasi Bisnis Komponen Bahan Baku Pada PT. Ega Nusantara. JMB : Jurnal Manajemen Dan Bisnis, 8(2). https://doi.org/10.31000/jmb.v8i2.1556.

Putra, N. P. (2020). Pemberdayaan Masyarakat Pada Kelompok Usaha Loloh Cemcem Di Desa Penglipuran Kabupaten Bangli. International Journal of Community Service Learning, 4(4). https://doi.org/10.23887/ijcsl.v4i4.29680.

Sahrupi, \& Shofa, M. J. (2019). Strategi Pemasar- An Produk Ke- Rajinan Casing Lampu Berbahan Kelurahan Pabuaran, Kota Serang. Wikrama Parahita: Jurnal Pengabdian Masyarakat, 3(2), 75-80. https://doi.org/https://doi.org/10.30656/jpmwp.v3i2.1791.

Samsiana, S., Herlawati, Nidaul Khasanah, F., Trias Handayanto, R., Setyowati Srie Gunarti, A., Irwan Raharja, Maimunah, \& Benrahman. (2020). Pemanfaatan Media Sosial dan Ecommerce Sebagai Media Pemasaran Dalam Mendukung Peluang Usaha Mandiri Pada Masa Pandemi Covid 19. Jurnal Sains Teknologi Dalam Pemberdayaan Masyarakat, 1(1), 51-62. https://doi.org/10.31599/jstpm.v1i1.255.

Setyowati, E., \& Puspa, A. (2019). Rekayasa Pengolahan Limbah Batok Kelapa Sebagai Aksesoris Sanggul. Jurnal Ilmiah Pendidikan Teknik Kejuruan ( JIPTEK ), 12(2), 118-127. https://doi.org/https://doi.org/10.20961/jiptek.v12i2.34161.

Sholeh, M., Triyono, J., \& Rachmawati, R. Y. (2020). Pendampingan Kelompok Informasi Masyarakat Dengan Memanfaatkan Marketplace Sebagai Media Pemasaran. Jurnal Penelitian Dan Pengabdian Kepada Masyarakat UNSIQ, 7(2), 158-164. https://doi.org/10.32699/ppkm.v7i2.965.

Siagian, A. O., Martiwi, R., \& Indra, N. (2020). Kemajuan Pemasaran Produk Dalam Memanfaatkan Media Sosial Di Era Digital. Jurnal Pemasaran Kompetitif, 3(3), 44. https://doi.org/10.32493/jpkpk.v3i3.4497.

Silaningsih, E., \& Utami, P. (2018). Pengaruh Marketing Mix Terhadap Minat Beli Konsumen Pada Usaha Mikro Kecil Dan Menengah (Umkm) Produk Olahan Makanan Ringan. Jurnal Sosial Humaniora, 144. https://doi.org/10.30997/jsh.v9i2.1382.

Sukmasetya, P., Haryanto, T., Sadewi, F. A., Maulida, R. B. G., Aliudin, H. S., \& Sugiarto, B. (2020). Pemanfaatan Digital Marketing sebagai Media Pemasaran Global untuk Meningkatkan Penjualan Produksi pada Home Industry. Community Empowerment, 5(2), 28-35. https://doi.org/10.31603/ce.v5i2.3514.

Trianto, B., \& ChoIvian. (2019). Analisis Pemasaran Online Kerajinan Temp urung Kelapa (Studi Kasus Kerajinan Tempurung Kelapa “ONI MADE” Desa Ngemplak, Kecamatan Undaan, Kabupaten Kudus). Universitas lslam Negri Walisongo Semarang.

Ulfah, S. C., \& Purfini, A. P. (2020). Implementasi Aplikasi Buku Kas Umum Berbasis Website Di Desa Ciwaruga Kecamatan Parongpong Kabupaten Bandung Barat. Jurnal Pengabdian Kepada Masyarakat Sistem Informasi Akuntansi, 1(1), 23-29. https://ojs.unikom.ac.id/index.php /abdikamsia/article/view/4588/2435.

Warsadi, K. A., Herawati, N. T., \& Julianto, I. P. (2017). Penerapan Penyusunan Laporan Keuangan Pada Usaha Kecil Menengah Berbasis Standar Akuntansi Keuangan Entitas Mikro, Kecil, Dan Menengah Pada PT. Mama Jaya. Jurusan Akuntansi, 8(2). https://ejournal.undiksha.ac.id/index. php/S1ak/article/view/13773/8561.

Zebua, A. J. (2018). Analisis Strategi Pemasaran Dalam Meningkatkan Volume Penjualan pada Shopie Paris BC. Yenni Kecamatan Muara Bulian. Jurnal Ilmiah Universitas Batanghari Jambi, 18(2), 222. https://doi.org/10.33087/jiubj.v18i2.468. 